\title{
ANNUAL MORAINE RIDGES AT SKÁLAFELLSJÖKULL, SOUTH-EAST ICELAND
}

\author{
By Martin Sharp \\ (Merton College and Department of Geology and Mineralogy, University of Oxford, Parks Road, Oxford OX1 3PR, England)
}

\begin{abstract}
Moraine ridges have formed annually at Skálafellsjökull, south-east Iceland since about A.D. 1912. These ridges are asymmetrical with a steeper distal slope, and their surface morphology reflects their internal structure. Most ridges are formed at the glacier margin, and they form a series of concentric arcs about it. Their plan form reflects small details of the ice-front morphology. Some ridges are composed of boulders released from the ice by ablation and swept together by glacier re-advances, but most have a core of deformed till. Those which were ice-cored have a surface veneer of resedimented debris consisting of ice-slope colluvium and sediment-flow deposits. Lodgement tills at Skálafellsjökull have a two-layer structure, with a weak upper horizon apparently formed by dilation during subglacial shearing of the till. Ridges are composed of this sheared material and overlie undisturbed lodgement till at depth. Subglacial shearing results in a discharge of till towards the glacier margin and its accumulation there when glacier retreat ceases in winter. Till may also be extruded from beneath ice at the margin as a result of loading by the ice, and subsequently bulldozed into a ridge by a winter readvance of the glacier.
\end{abstract}

RÉsumÉ. Arcs morainiques annuels an Skälafellsjökull, Sud-Est de l'Islande. Des cordons morainiques se sont formés chaque année au Skálafellsjökull dans le Sud-Est de I'Islande depuis environ 1912. Ces cordons sont asymétriques, avec la face éloignée plus abrupte, et leur morphologie de surface reflete leur structure interne. La plupart de ces cordons se forment sur l'extrémité du glacier et forment une série d'arcs concentriques autour de lui. Leur forme plane révèle quelques détails de la morphologie du front glaciaire. Quelques cordons sont composés de blocs tombés de la glace au cours de l'ablation et rassemblés par la poussée d'une nouvelle avance du glacier, mais la plupart ont un coeur constituté d'argile glaciaire déformée. Ceux qui sont à coeur de glace présentent un placage superficiel de matériaux re-déposés sous forme de colluvium du bas de pente englacée ou de sédiments hydriques. Les moraines de fond ou Skálafellsjökull ont une

\section{INTRODUCTION}

Sequences of ridges, referred to as minor moraines, produced during the recession of valley glaciers have frequently been described in the literature, and it has often been suggested that they are formed annually in association with winter re-advances of the glacier margin (Thorarinsson, 1967; Andersen and Sollid, 1971; Price, 1970; Worsley, 1974; Birnie, 1977). This has only rarely been proven by direct observation, however, and the processes involved in ridge construction remain a matter for debate. A variety of possibilities have been suggested, including squeezing of watersoaked till from beneath the glacier margin (Price, 1970), melt-out of thick englacial debris bands (Andersen and Sollid, 1971), snow-bank push (Birnie, 1977, unpublished), bulldozing by the glacier (Worsley, 1974), and dumping of supraglacially transported debris on to the pro-glacial sediment surface (Lawson, 1979[b]; Eyles, 1979). Though some studies invoke single processes to explain ridge construction, it is probable that more than one process can contribute to the formation of ridges at any one glacier (Rogerson and Batterson, 1982).

An unusually long sequence of 40 to 60 minor moraines which occurs in front of Skálafellsjökull. south-east Iceland (Fig.1) is described in this paper. Skălafellsjökull flows from the Breiōabunga plateau in eastern Vatnajökull for over $30 \mathrm{~km}$ and terminates at an altitude of $60 \mathrm{~m} \mathrm{a.s.l.} \mathrm{on} \mathrm{the} \mathrm{coastal} \mathrm{plain}$ of Hornafjördur approximately $15 \mathrm{~km}$ west of Höfn. It drains a $260 \mathrm{~km}^{2}$ catchment (Kasser, 1967) in which the bedrock geology consists largely of west-dipping basalt lavas interstratified with tuffs and tillites. structure à deux niveaux avec un horizon supérieur mince apparemment formé par la dilatation au cours du cisaillement sous-glaciaire de l'argile morainique. Les cordons sont composés de ce matériel étiré et surmontent une moraine de fond non remaniée en profondeur. Les cisaillements sousglaciaires provoquent un acheminement de l'argile morainique vers les rive du glacier et son dépôt sur place lorsque le retrait du glacier cesse en hiver. L'argile morainique peut aussi faire extrusion de dessous la glace vers la rive, à cause de son chargement par la glace et être ensuite poussée dans un cordon par une réavance hivernale du glacier.

Zusammenfassung. Jahres-Moränenrücken am Skälafellsjökull, Südost-Island. Moränenrücken bilden sich alljährlich seit etwa 1912 am Skálafellsjökull in Südost-Island. Diese Rücken sind asymmetrisch mit einem steileren Abfall nach aussen und ihre Oberflächenform spiegelt ihre innere Struktur wider. Die meisten Rücken sind am Gletscherrand entstanden und bilden eine Serie konzentrischer Bögen um den Gletscher. Ihre Grundrissform folg kleinen Einzelheiten der Gestalt der Eisfront. Einige Rücken bestehen aus Blöcken, die durch Ausschmelzung abgelagert und bei Gletschervorstössen zusammengeschoben wurden, aber die meisten haben einen Kern aus deformiertem Geschiebe. Solche, die einen Eiskern besassen, haben eine Oberflächenhaut von wiederabgelagertem Schutt, die aus Geröll und Fliesssedimenten besteht. Die Geschiebe am Skálafellsjökull besitzen eine Zwei-Schichten-Struktur mit einem schwachen oberen Horizont, der sichtlich durch Verschiebung bei der subglazialen Scherung entstanden ist. Die Rücken bestehen aus diesem gescherten Material und überlagern ungestörte Geschiebe in der Tiefe. Subglaziale Scherung führt zu einem NettoAusstoss von Geschiebe gegen den Gletscherrand und seiner Ansammlung dort, wenn der Gletscherrückgang im Winter aufhört. Geschiebe kann auch unterhalb des Eises am Rand als Ergebnis der Beladung durch das Ei ausgestossen und anschliessend durch einen winterlichen Vorstoss des Gletschers zu einem Rücken zusammengeschoben werden.

There is a gabbro intrusion beneath the southern margin of the glacier at pormodarhnuta, and acid volcanic rocks and palagonite tuffs occur in the upper part of the catchment (Walker, 1964). Breiðabunga may be a subglacial central volcano complex (Saemundsson. [1980]).

Skálafellsjökull reached its maximum extent in historical times in A.D. 1887 (Thorarinsson, 1943), and the limit of this advance is marked by a $10-15 \mathrm{~m}$ high end moraine. Between 1887 and 1972 the glacier retreated a total of $1713 \mathrm{~m}$ and experienced on ly two extended re-advances, in 1932-33 and between 1966 and 1969 (Eythōrsson, 1963; Rist, [1976]). No measurements of ice margin fluctuations have been made since 1972 . At present, the glacier terminates in a $3 \mathrm{~km}$ wide zone running from the sandur plain of Heinabergsvötn in the north to an area of basalt roches moutonnees overlooking the river Kolgrimá in the south. It is fronted by two pro-glacial lakes, the largest on Heinabergsvötn and a smaller one in the bedrock area to the south (Fig.1). This study was largely carried out within the area of roches moutonnees, bedrock landforms veneered with a discontinuous sheet of fluted lodgement till up to $3 \mathrm{~m}$ thick, and with occasional kame terraces on their stoss slopes (Sharp, unpublished).

\section{MORPHOLUGY OF THE RIDGES}

The 40 to 60 ridges which lie between the 1887 end moraine and the present margin of Skälafells sökull form a series of concentric arcs about the glacier margin (Fig.1). Many ridges are continuous over considerable distances, but others are more broken, particularly where the sediment cover is thin and bould- 


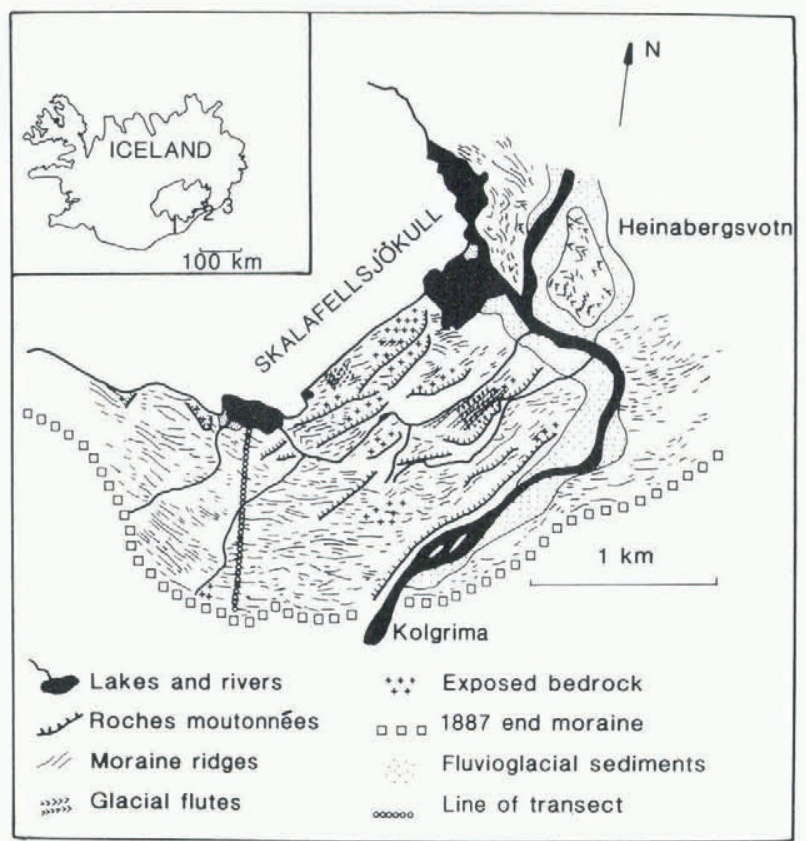

Fig.1. Geomomphological map of the pro-glacial area of Skalafellsjokull in 1979. The line of transect along which the Iceland Glaciological Society made its annual measurements of glacier retreat is indicated. Inset: Map of Iceland, showing the location of 1. Fagurhol smym; 2. Skálafellsjokull; and 3. Ḧ̈fn.

ery. Complexities of pattern result from the overriding and superposition of ridges of different ages (Fig.2), but the plan form of ridges appears to reflect details of the ice-front morphology, and it is suggested that they represent successive former icefront positions. In areas where the ice margin is dissected by radial crevasses, ridges have a characteristic saw-tooth form (Matthews and others, 1979), but where the glacier is less intensely crevassed the plan form is more linear.

Along the present glacier margin, recently formed and actively forming ridges were observed in the following positions:

1. Immediately in contact with the active glacier margin (Fig.3);

2. At the distal edge of a marginal snowbank, a situation similar to that described by Birnie (1977) (Fig.4);

3. Along the shore of a pro-glacial lake, where the ridge appeared to have formed in relationship to a winter lake-ice cover which may have been pushed forward by the glacier; and

4. At the base of the up-glacier wall of an abandoned tunnel cut up into the ice by a submarginal melt-water stream.

The cross-section morphology of ridges was determined by Abney level and tape traverse of 59 ridge segments. The height of individual ridges above the ground surface ranged from 0.4 to $5.25 \mathrm{~m}$ (mean $1.52 \pm 0.96 \mathrm{~m}$ ) and the width of the ridges between the breaks in slope at the foot of their proximal and distal slopes was between 1.6 and $18.65 \mathrm{~m}$ (mean $6.6 \pm 3.5 \mathrm{~m}$; Table I). The relationship between the width $w$ and height $h$ of ridges is summarized by the least-squares regression equation:

$$
\omega=1.74 m+3.19 h(r=0.87 ; p<0.001) .
$$

The maximum slope angle recorded was $35.5^{\circ}$ on a oneyear-old ridge. Measurements of ridge morphology were used to calculate the "asymmetry index" A suggested by Matthews and others (1979):

$$
A=h / w \tan \theta_{\mathrm{p}}
$$

where $\theta_{p}$ is the proximal slope angle.

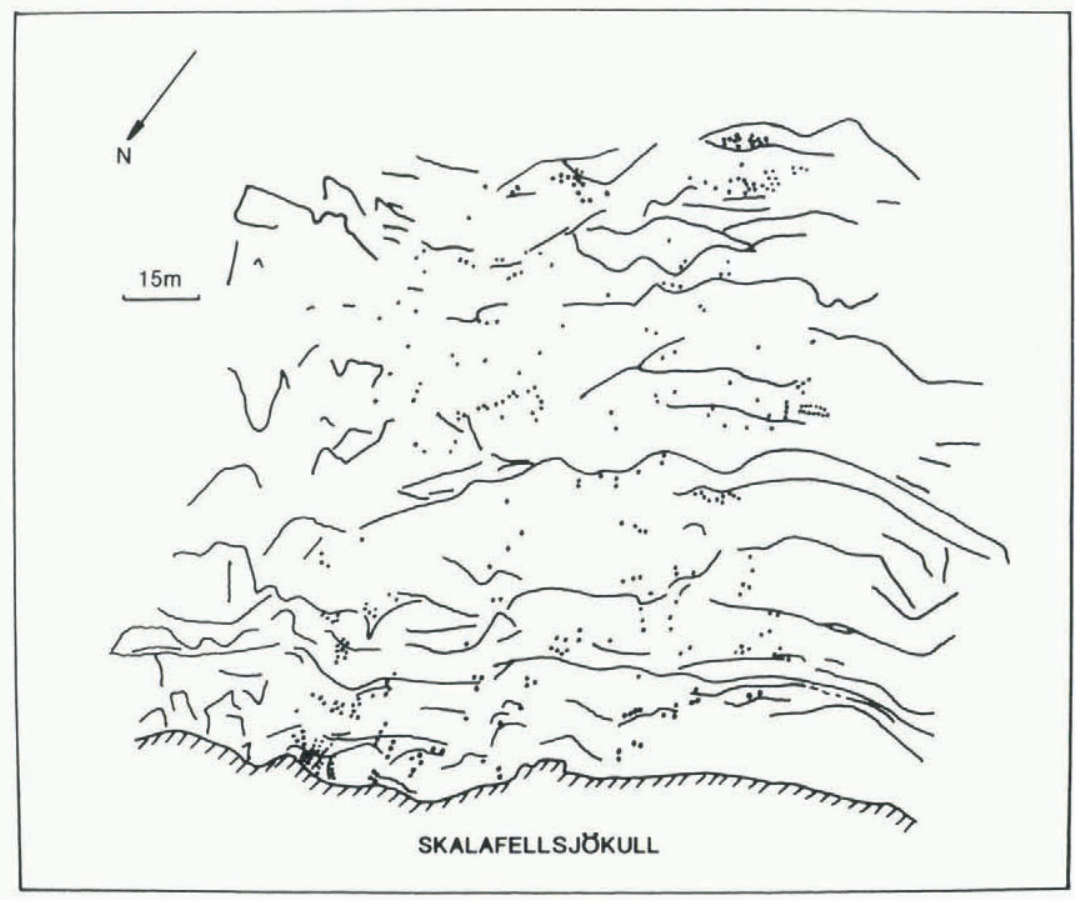

Fig.2. Plane-table map of the crest-line positions of recent "annual" monaine midges at Skalafellsjökull. The location of all boulders greater than $0.5 \mathrm{~m}$ in diameter is also shown. Mapping was carried out in August 1980 . 


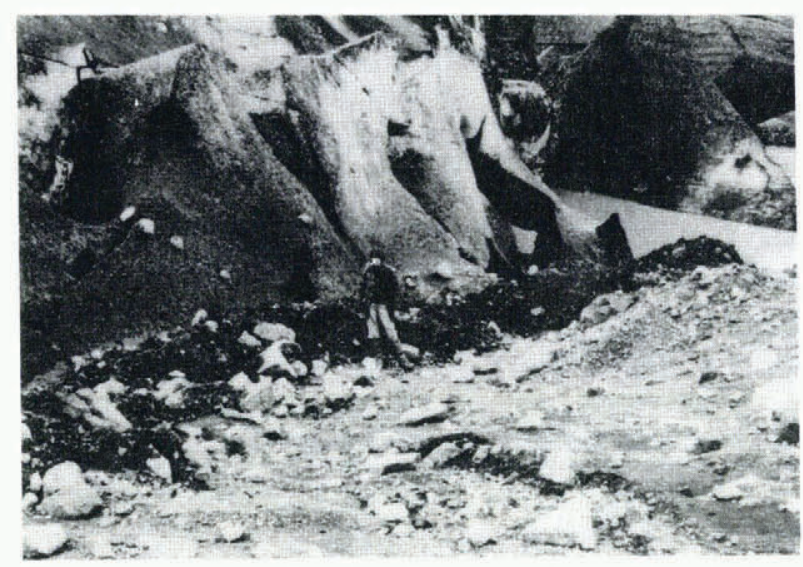

Fig.3. Type A moraine midge formed during the winter 1979-80 in contact with the steep, actively sliding margin of skálafelzsjokulz.

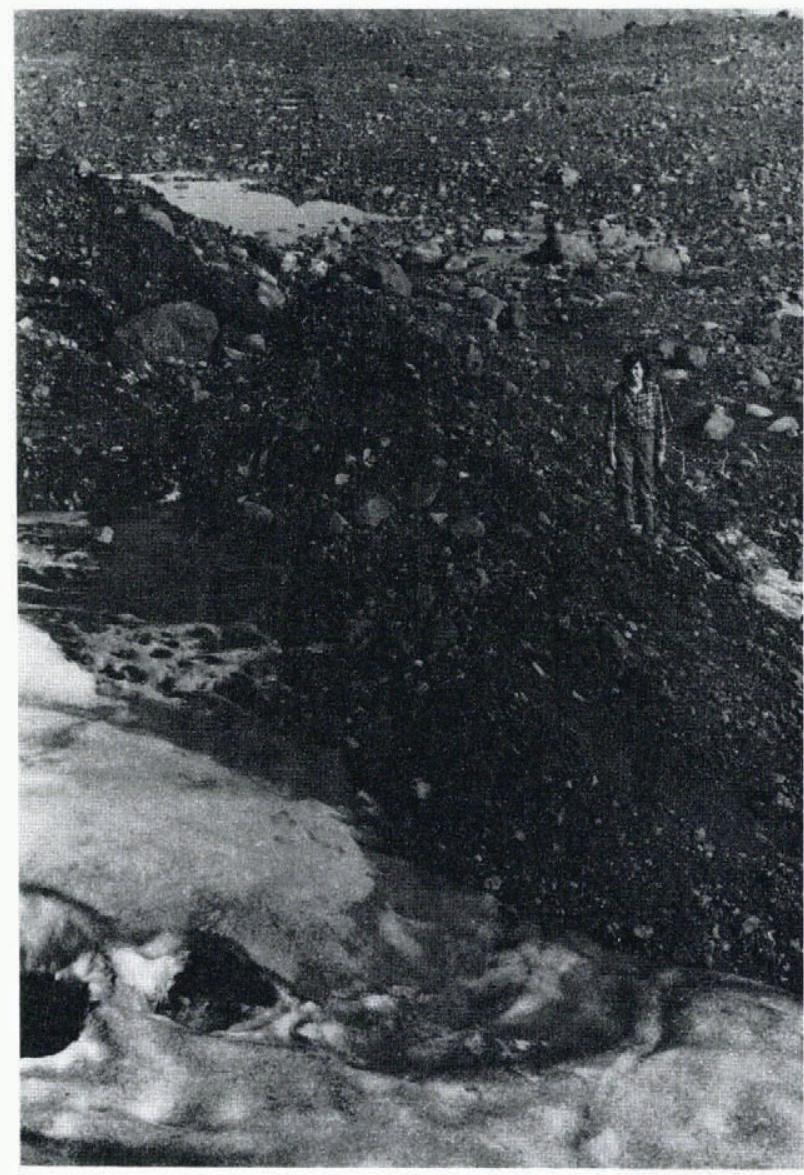

Fig.4. Type D moraine midge formed at the distal edge of an ice-marginal snowbank. The snowbank has become incorporated into the midge as a result of the flow of midge sediments over its surface.

A value for $A$ of 0.5 denotes perfect symmetry. For the ridges measured in this study, $A$ ranges from 0.45 to 1.33 (mean $0.69 \pm 0.15$; Table I), indicating that they are asymmetrical. The difference between proximal and distal slope angles was between $0^{\circ}$ and $13.5^{\circ}$, but either proximal or distal slope could be steeper. Although most ridges appeared to have steeper distal slopes, this was often not the case for ridges deposited on surfaces dipping up-glacier, presumably because the dip of the depositional surface had the effect of increasing the proximal slope angle. A separate analysis was carried out on 16 profiles for which differences in elevation between the breaks of slope at the foot of distal and proximal slopes was less than $20 \mathrm{~cm}$ (Table II). The mean asymmetry of these profiles was $0.69+0.23$, and the distal slopes were on average $5.1^{\circ}$ steeper than the proximal slopes. The hypothesis that distal slopes were steeper than proximal was tested using Wilcoxon matched-pairs signed ranks test (Siegel, 1956), and the difference was found to be significant at the 0.005 level.

Near the crest-lines of roches moutonnees the sediment cover is thin and bouldery, and ridges consist of linear accumulations of boulders separated by expanses of bare bedrock. As Skálafellsjökull has no appreciable surface cover of coarse debris, these ridges are unlikely to be dump ridges of the type described by Eyles (1979) or Rains and Shaw (1981). Observation suggests that the boulders are released from the basal ice of the glacier by ablation, and subsequently swept together by small re-advances of the glacier to form discontinuous ridges.

Where the sediment cover is thicker, more complex ridge forms develop, and four distinct types were identified (Fig.5):

1. Type A ridges are the most common form. They are formed at the glacier margin and consist of a till ridge with a fluted proximal slope which has been overridden by the glacier. Sediment flow activity on the distal slope of some ridges results from saturation of the ridge sediments with melt waters from the adjacent glacier.

2. Type $B$ ridges are found along thin, gently inclined ice margins. They have a core which is essentially a Type A ridge, but they also have an ice core and a surface veneer of re-sedimented debris (Lawson, 1979[b]) on the proximal slope. The ice core forms in summer when ice in contact with the ridge melts downwards and the ridge sediments become saturated with melt water and flow back down the proximal slope to bury the glacier margin.

3. Type $C$ ridges form where thick debris bands, the origin of which can be traced to the glacier bed within a few metres of the margin, crop out on the ice surface above a Type A ridge (Fig.6). The debris bands are exposed by back-wasting of the overlying clean ice slopes, and they insulate the underlying ice which then becomes incorporated into the proximal slope of the ridge. As the ice core melts out, the debris-band sediments are resedimented by flow, slump, and fall processes. Flows are particularly common on proximal slopes, and scree-type deposition and size sorting occur on the distal slopes.

4. Type D ridges occur where the glacier is in contact with a marginal snowbank. As the snowbank is pushed forward by the glacier, small ridges may form at its distal limit. Where the snowbank is overridden by the glacier sole, debris melted from the basal ice is resedimented over it by sediment flows and the snowbank may become incorporated into the ridge structure (Fig.4). A low ridge may form as the snowbank melts out from beneath this debris cover.

\section{SEDIMENTULOGY AND STRUCTURE OF THE RIDGES}

In order to determine the origin of the sediments of which the cores of Types A, B, and C ridges are composed, 21 two kilogramme samples of the fraction finer than $-4 \phi$ were returned to the laboratory for analysis. The particle-size composition of the sediments was determined by overlapping dry-sieve, wetsieve, and hydrometer methods, and samples were classified texturally on the basis of the position in which they plot on a gravel $(>-1 \phi)$, sand $(-1 \phi$ to $4 \phi)$, and silt and clay $(<4 \phi)$ ternary diagram (Fig.7a).

The classification scheme of Lawson (1979[b], p.86) was used. The four graphical statistical measures in- 
TABLE I. THE MORPHOLOGICAL CHARACTERISTICS OF ANNUAL MORAINE RIDGES AT SKALAFELLSJOKULL

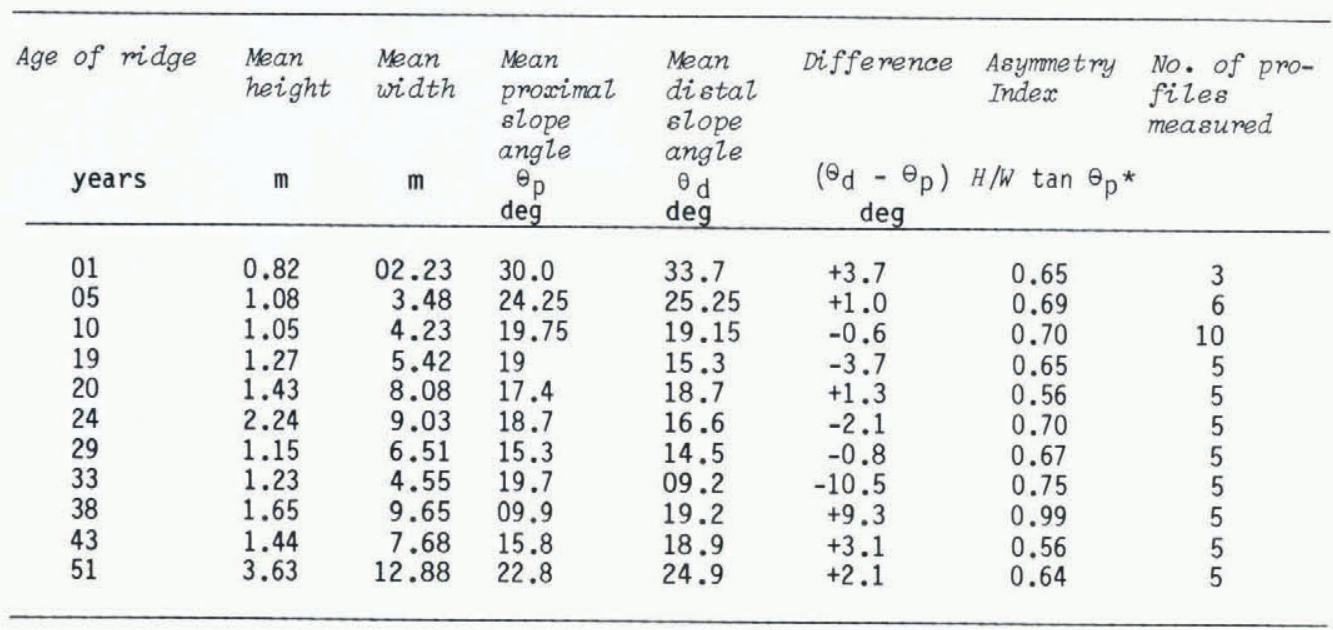

* 0.5 denotes perfect symmetry

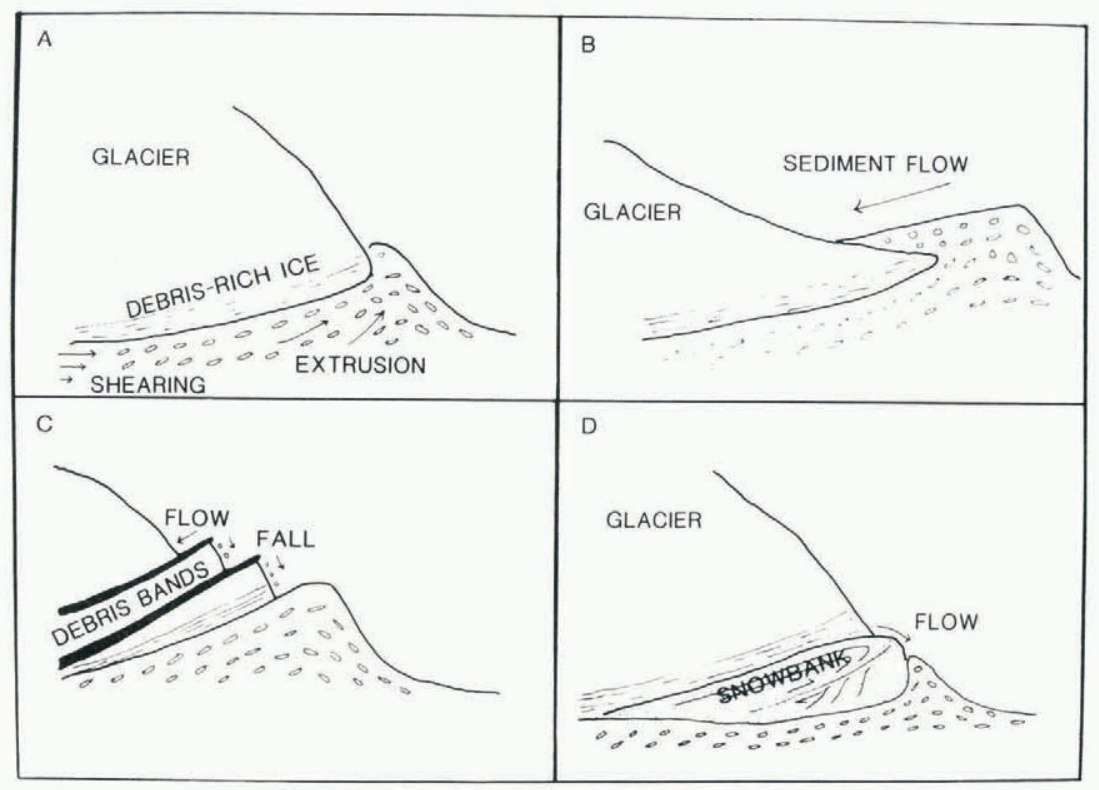

Fig.5. Diagram showing the four types of moraine midges observed at Skálafellsjökull.

A. Simple midge formed of deformed lodgement till. $B$. Ridge with an ice core incorporated by the flow of ridge sediments back over the glacier margin. C. Ridge with an ice core isolated beneath thick englacial debris bands which have been exposed by backwasting of the overlying ice slopes.

D. Ridge formed at the distal edge of a marginal snowbank which has been pushed forward by the glacier.

Flow of debris derived from the basal ice has incor porated the snowbank into the midge.

clusive graphic mean ( $\mathrm{Mz})$, inclusive graphic standard deviation $\left(\sigma_{j}\right)$, inclusive graphic-skewness $\left(S k_{j}\right)$, and graphic kurtosis $(\mathrm{kg})$ were calculated as described by Folk and Ward (1957).

The sediments were black (5Y 2/1) to very dark grey $(5 Y 3 / 1)$ in colour and consisted of very poorly to extremely poorly sorted $\left(\bar{\sigma}_{j}=3.83 \pm 0.40 \phi\right)$, positively to very negatively skewed $\left(\overline{S K}_{j}=0.11 \pm 0.19\right)$, sandy gravels, sandy silts, and gravelly silty sands $(\overline{\mathrm{Mz}}=1.87 \pm 1.54 \phi)$. The average particle-size distribution was bimodal, with the principal mode lying between 0 and $-4 \phi$ and the secondary mode between 2 and $6 \phi$ (Fig. $7 \mathrm{~b})$. The fraction coarser than $-5 \phi$ was a mixture of basalt and gabbro clasts, with a few clasts of tuff, tillite, and ultrabasic rocks, while the clay fraction was a mixture of smectite and chlorite with traces of zeolite and plagioclase felspar (personal communication from M.J. Wilson in 1982). The Zingg shape (Zingg, 1935), Powers roundness (Powers, 1953), and the occurrence of striations on 771 clasts coarser than $-5 \phi$ was determined in the field. $55.3 \%$ of these clasts were striated, $0.7 \%$ were very angular, $7.7 \%$ angular, $27.3 \%$ sub-angular, $51.6 \%$ sub-rounded, $11.7 \%$ rounded and $1.9 \%$ wel1rounded. The Zingg shape distribution was $46.3 \%$ spheres, $31.4 \%$ discs, $18.2 \%$ rods, and $4.4 \%$ biades. 
TABLE II, MORPHOLOGY OF 16 INDIVIDUAL RIDGE CROSS PROFILES FROM AREAS WHERE THE DEPOSITIONAL SURFACE WAS APPROXIMATELY HORIZONTAL

\begin{tabular}{|c|c|c|c|c|c|c|}
\hline $\begin{array}{c}\text { Ridge age } \\
\text { years }\end{array}$ & $\begin{array}{c}\text { Height } \\
\text { m }\end{array}$ & $\underset{\mathrm{m}}{\text { Width }}$ & $\begin{array}{r}\text { Op } \\
\text { deg }\end{array}$ & $\begin{array}{r}\Theta_{d} \\
\text { deg }\end{array}$ & $\theta_{d e g}^{-} \theta_{p}$ & $H / W \tan$ \\
\hline 01 & 0.65 & 2.2 & 26 & 32 & +6 & 0.61 \\
\hline 10 & 0.4 & 2.4 & 12 & 19.5 & +7 & 0.78 \\
\hline 10 & 0.6 & 3.4 & 18 & 19 & +1 & 0.55 \\
\hline 10 & 0.63 & 3.6 & 16.5 & 24 & +7.5 & 0.59 \\
\hline 19 & 0.8 & 4.15 & 18.5 & 17 & -1.5 & 0.58 \\
\hline 20 & 0.85 & 5.4 & 17 & 18 & +1 & 0.52 \\
\hline 20 & 1.3 & 8.1 & 17 & 18 & +1 & 0.52 \\
\hline 20 & 1.4 & 7.9 & 17 & 22 & +5 & 0.58 \\
\hline 29 & 0.85 & 7.9 & 10 & 15 & +5 & 0.61 \\
\hline 29 & 0.8 & 7.7 & 9 & 18 & +9 & 0.66 \\
\hline 38 & 1.0 & 7.0 & 8 & 19 & +11 & 1.02 \\
\hline 38 & 1.05 & 8.25 & 5.5 & 20.5 & +15 & 1.33 \\
\hline 38 & 1.9 & 10.25 & 12 & 20.5 & +8.5 & 0.87 \\
\hline 43 & 0.7 & 5.7 & 13 & 14 & +1 & 0.53 \\
\hline 43 & 0.95 & 7.05 & 10 & 16 & +6 & 0.77 \\
\hline 43 & 0.7 & 4.9 & 17.5 & 16.5 & -1 & 0.45 \\
\hline
\end{tabular}

The relatively high silt and clay content of the samples $(33.8 \pm 13.3 \%)$, the high proportion of striated clasts, and the dominantly sub-angular to sub-rounded clast shapes all suggest that the debris had passed through the zone of traction at the glacier sole (Boulton, 1978). This is confirmed by studies of the distribution of debris within Skálafellsjökull (Sharp, unpublished), which indicate that almost the entire debris-load of the glacier is transported within $3 \mathrm{~m}$ of the bed, and that there is a near complete absence of coarse-grained supraglacial and englacial debris. The ridge sediments have similar particle size and form characteristics to the sediments which occur in inter-ridge areas. These were identified as lodgement tills by Sharp (unpublished) because they have a well developed and regionally consistent pebble fabric, contain clasts with a stoss and lee form and consistently orientated striae (Sharp, 1982), and have a fluted upper surface which exhibits grooves and $t i l l$ wedges indicative of lodgement by a ploughing process. It seems likely, therefore, that the ridge sediments are derived from these adjacent lodgement tills.

Comparison of the till characteristics with those of five samples of debris from the basal ice of the glacier shows that the tills contain significantly more silt and clay than the debris from the basal ice $(33.8 \pm 13.3 \%$ compared to $17.6 \pm 8.2 \%$; MannWhitney $U$-test, $U=18, p<0.01)$, and a greater proportion of striated clasts ( $55.3 \%$ compared to $22.0 \%$ ). One possible explanation of these observations is that much of the clast striation and production of silt and clay occurred after deposition of the debris when it was sheared beneath the glacier in the manner described by Boulton (1979), Boulton and others (1974), and Boulton and Jones (1979). When sediments are deformed subglacially, particles are confined either by ice or by other sediment particles; the presence of a confining pressure in the area of contact between two particles is likely to suppress brittle fracture (Bowden and Tabor, 1950), with the result that debris comminution occurs by inter-particle abrasion (Slatt and Eyles, 1981), which appears to produce silt and clay-sized particles (Boulton, 1978).

Studies of the structure and vane shear strength of Skālafellsjökull lodgement tills provide further support for this suggestion. 250 measurements of the in situ shear strength of lodgement tills in subglacial tunnels or which had been exposed for less than one year were made with a Tor vane. These measurements should only be considered to provide a relative

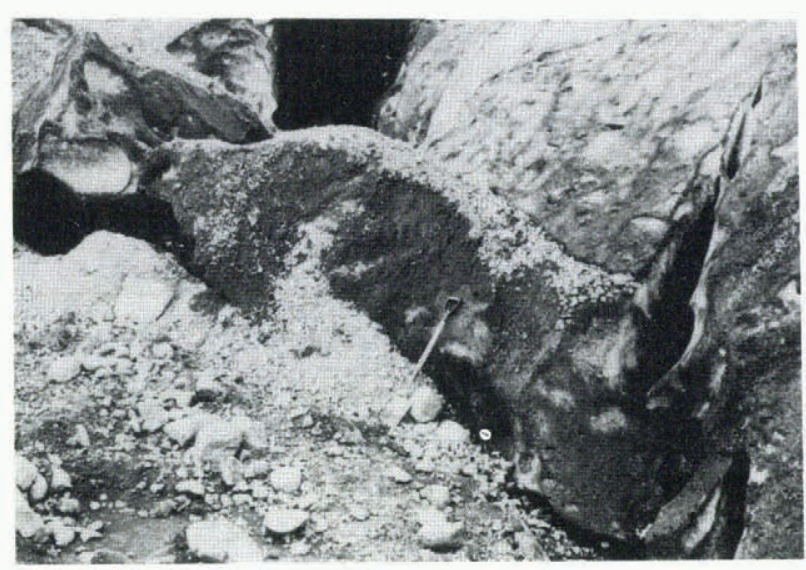

Fig.6. Outcrop of thick englacial debris band at the margin of skálafellsjokull. Debris fallen from the band is accumulating at the base of the slope, and down-slope size sorting is apparent on the resulting scree.

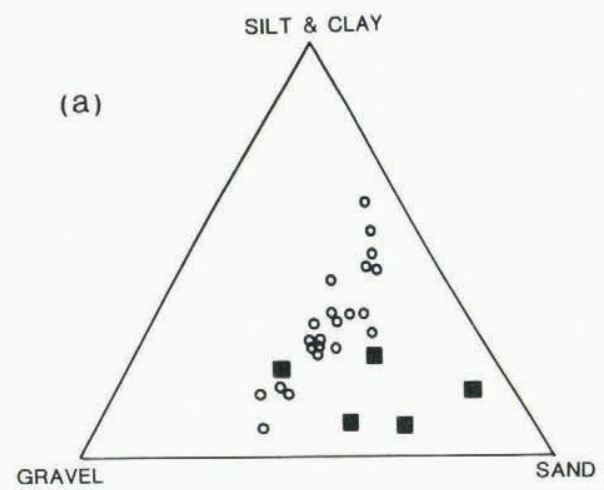

(b)

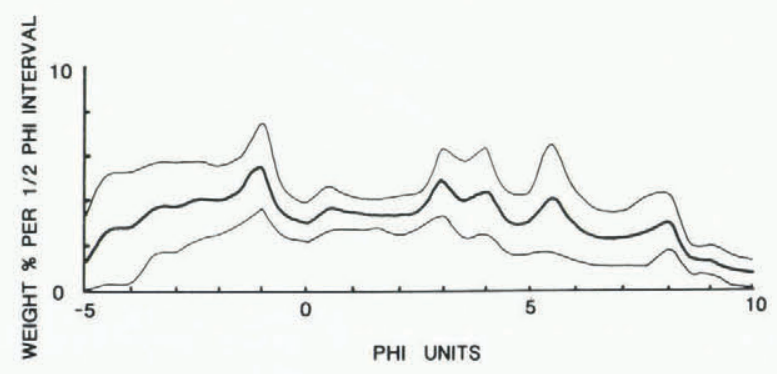

Fig.7. a. Temary diagram showing grain size of lodgement tills (O) and debris from the basal transport zone of Skálafellsjökull (⿴).

b. Mean particle-size composition ( \pm 1 standard deviation) of lodgement tills at Skälafellsjökull.

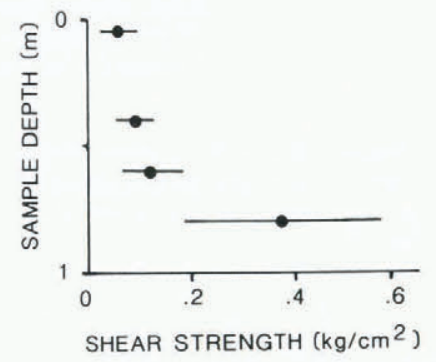

Fig.8. Diagram showing the relationship between the mean in situ shear strength $( \pm 1$ standard deviation) of subglacial and recently exposed lodgement till at skalafellsjökulz and depth below the till surface. 


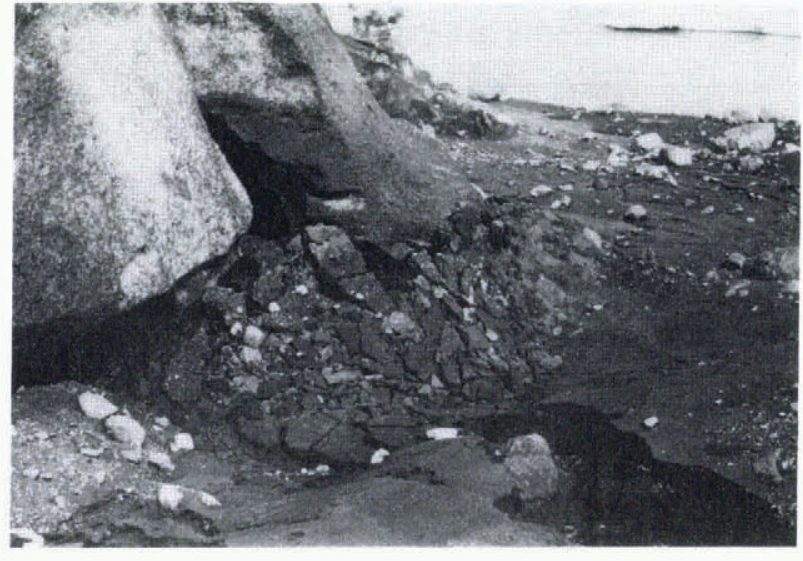

Fig.9. Ridge formed from pro-glacially-deposited sands and silts which have been tilted and disaggregated by the advancing glacier. Coarse debris on the sur face of the midge has fallen from the overlying ice slope.

measure of the matrix strength of the tills, as the Tor vane is strictly only applicable for determining the in situ shear strength of "soft" clays and silts. Nevertheless, when the readings are plotted against depth (Fig.8) it is possible to distinguish an upper horizon up to $70 \mathrm{~cm}$ thick in which shear strength increases only slightly with depth and is generally less than $0.2 \mathrm{~kg} \mathrm{~cm}-2$, and a lower horizon with sub-

stantially greater strength $\left(0.33 \pm 0.196 \mathrm{~kg} \mathrm{~cm}^{-2}\right)$.

In the field, the upper horizon appears as a massive, loose, and poorly consolidated till with obvious vesicular pores; the lower horizon is denser, better consolidated, and contains sub-horizontal joints which give it a fissile structure, and a conjugate set of sub-vertical joints with clean faces. These character istics indicate a two-layer structure similar to that of lodgement tills at Breidamerkurjökull (Boulton and Dent, 1974; Romans and others 1980) in which subglacial shearing has been shown to occur by direct measurement (Boulton and Jones, 1979). The upper horizon is probably caused by dilation during subglacial shearing, and its occurrence in the Skälafellsjökull lodgement tills suggests that these have also experienced subglacial shearing.

Although most ridges consisted of massive till, two showed internal structures which contribute to the understanding of their formation. The first, still in contact with the glacier, was composed of stratified sands and silts (Fig.9), and although these sediments had broken up into blocks which had suffered relative movement and partial overturning, it was still possible to pick out the internal structure of the ridge. This was an asymmetrical fold with a steeper distal limb, an axial plane dipping up-glacier with its axis parallel to the glacier margin. The morphology of the ridge was a reflection of this structure.

The second ridge contained a lens of stratified sand and silt resting on a former ground surface but partially buried by the till which formed the ridge (Fig.10). The layering within the buried part of the lens picked out an overfold with an axial plane which dipped gently up-glacier and which was cut by a lowangle thrust fault. This structure indicates that the lens was involved in the deformation associated with ridge construction. The partial burial of the lens suggests that it was formed pro-glacially and then buried during ridge construction.

37 sets of pebble fabric measurements were made in sections excavated through ridges. In each case, the $a$-axis orientation and dip of either 25 or 50 pebbles with $a: b$ axis ratios of $\geqslant 1.5$ were measured to the nearest $5^{\circ}$. Samples of 25 were chosen when more than two sets of measurements were made in a

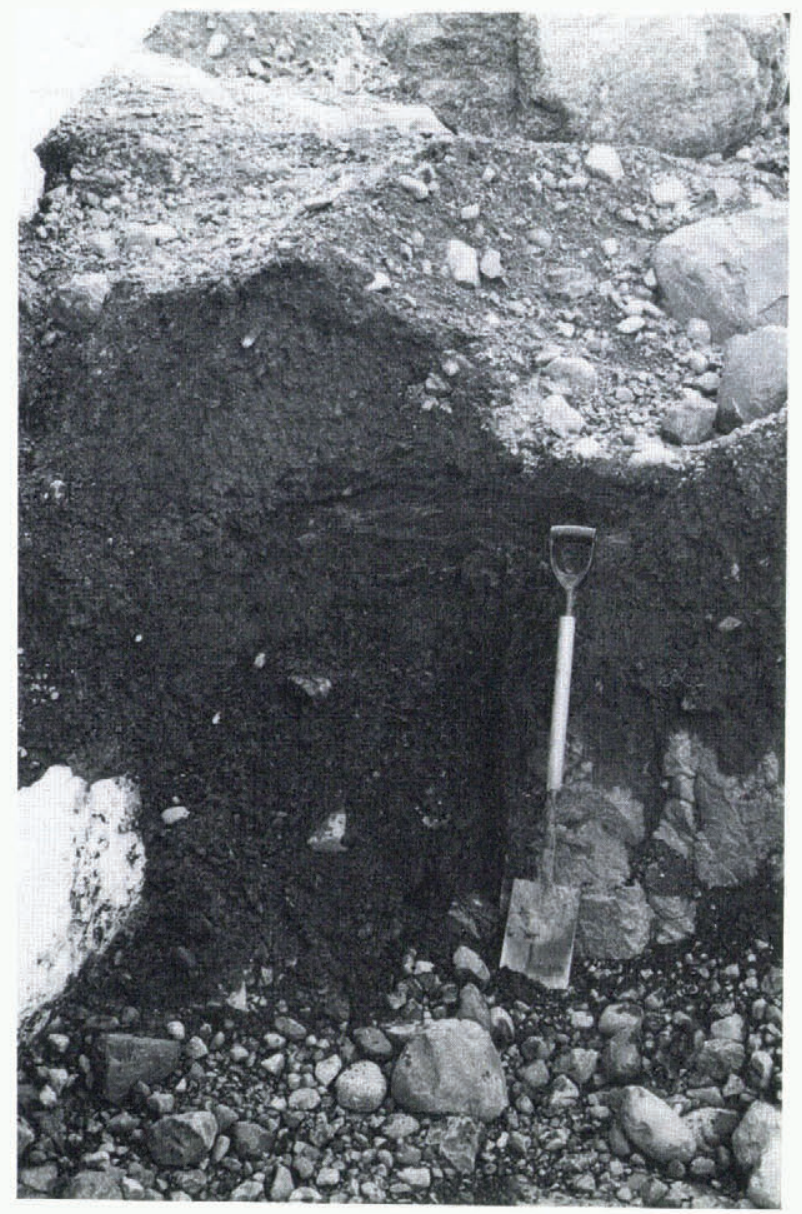

Fig.10. Lens of parallel laminated sand and silt par tially bumied beneath the till core of an "annual" moraine midge at Skalafellsjokull. Note the over fold and thmust picked out by the silt laminae at the left side of the lens.

single ridge. Samples were usually taken from a $50 \mathrm{~cm} \times 50 \mathrm{~cm}$ horizontal surface excavated with a trowel. The measurements are plotted as equal-area nets (lower hemisphere projection) contoured according to the methods of Kamb (1959) at an interval of $2 \sigma$. The measurements were analysed using the $A_{n}$ statistics developed by Ajne (1968) and Stephens (1969). These statistics test for the departure of

TABLE III. TYPES OF FABRIC DISTINGUISHED BY THE $A_{n}$ STATISTICS OF AJNE (1968) AND STEPHENS (1969)
Type $A_{n} 360$
$A_{n} 180$
Interpretation

A Significant Significant Both trend and $(p<0.05)$ plunge of fabric are significantly different from a uniform distribution.

B Not

C Significant Not

Plunge only significant

D Not Not Uniform

Significant Significant distribution 
TABLE IV. CHARACTERISTICS OF PEBBLE FABRICS FROM ANNUAL MORAINE RIDGES AT SKÁLAFELLSJOKULL, AND VARIABILITY WITH RESPECT TO POSITION WITHIN A RIDGE

\begin{tabular}{|c|c|c|c|c|c|c|c|}
\hline a. & $\begin{array}{c}\text { Depth of sample } \\
\text { below ridge crest } \\
\mathrm{cm}\end{array}$ & $\begin{array}{c}\text { Mean vector } \\
\text { magnitude }(L) \\
\%\end{array}$ & $\begin{array}{l}\text { Type } A \\
\text { fabric }\end{array}$ & $\begin{array}{l}\text { Type } B \\
\text { fabric }\end{array}$ & $\begin{array}{l}\text { Type C } \\
\text { fabric }\end{array}$ & $\begin{array}{l}\text { Type } D \\
\text { fabric }\end{array}$ & $n$ \\
\hline & $\begin{aligned} 0 & -59 \\
60 & -119 \\
120 & -179 \\
& \geqslant 180\end{aligned}$ & $\begin{array}{l}36.7 \\
38.2 \\
47.0 \\
65.3\end{array}$ & $\begin{array}{l}5 \\
6 \\
1 \\
4\end{array}$ & $\begin{array}{l}6 \\
3 \\
1 \\
0\end{array}$ & $\begin{array}{l}5 \\
1 \\
1 \\
0\end{array}$ & $\begin{array}{l}2 \\
1 \\
1 \\
0\end{array}$ & $\begin{array}{r}18 \\
11 \\
4 \\
4\end{array}$ \\
\hline & $\begin{array}{l}\text { Position of } \\
\text { sample with re- } \\
\text { spect to ridge } \\
\text { crest }\end{array}$ & $\begin{array}{l}\text { Mean vector } \\
\text { magnitude }(L) \\
\%\end{array}$ & $\begin{array}{l}\text { Type } A \\
\text { fabric }\end{array}$ & $\begin{array}{l}\text { Type } B \\
\text { fabric }\end{array}$ & $\begin{array}{l}\text { Type C } \\
\text { fabric }\end{array}$ & $\begin{array}{l}\text { Type } D \\
\text { fabric }\end{array}$ & $n$ \\
\hline & $\begin{array}{l}\text { PROXIMAL } \\
\text { CENTRAL } \\
\text { DISTAL }\end{array}$ & $\begin{array}{l}40.8 \\
36.1 \\
44.6\end{array}$ & $\begin{array}{l}9 \\
3 \\
4\end{array}$ & $\begin{array}{l}3 \\
0 \\
7\end{array}$ & $\begin{array}{l}3 \\
0 \\
4\end{array}$ & $\begin{array}{l}3 \\
1 \\
0\end{array}$ & $\begin{array}{r}18 \\
4 \\
15\end{array}$ \\
\hline
\end{tabular}

c. Occurrence of down-glacier-dipping fabric elements:

\begin{tabular}{|c|c|c|c|c|}
\hline Fabric type & Dip direction & $\begin{array}{l}\text { Proximal } \\
\text { position }\end{array}$ & $\begin{array}{l}\text { Distal } \\
\text { position }\end{array}$ & Total \\
\hline $\begin{array}{l}A \\
C \\
A \\
C \\
B\end{array}$ & $\begin{array}{l}\text { Up-glacier } \\
\text { Up-glacier } \\
\text { Down-glacier } \\
\text { Down-glacier } \\
\text { Both }\end{array}$ & $\begin{array}{l}9 \\
3 \\
0 \\
0 \\
3\end{array}$ & $\begin{array}{l}3 \\
2 \\
1 \\
2 \\
7\end{array}$ & $\begin{array}{r}12 \\
5 \\
1 \\
2 \\
10\end{array}$ \\
\hline $\begin{array}{l}\text { Total fabrics with } \\
\text { up-glacier-dipping } \\
\text { element }\end{array}$ & & 15 & 12 & \\
\hline $\begin{array}{l}\text { Total fabrics with } \\
\text { down-glacier- } \\
\text { dipping element }\end{array}$ & & 3 & 10 & \\
\hline $\begin{array}{l}\text { Total no. of fabrics } \\
\text { measured (including } \\
\text { Type D) }\end{array}$ & & 18 & 15 & 33 \\
\hline
\end{tabular}

a fabric from a uniform distribution over both $360^{\circ}$ ( $A_{n} 360$ statistic) and $180^{\circ}\left(A_{n} 180\right.$ statistic). In the latter case, no account is taken of particle dip. Stephens (1969) provides tables of significance. The statistics yield two values which, when taken together, allow four fabric types, A, B, C, and D, to be recognized (Table III). The $A_{n}$ statistics provide tests which are invariant with respect to the point of origin of the measurements, do not assume a circular normal distribution, and place no limitation on sample size (Dale and Ballantyne, 1980). It is therefore valid to use them for the analysis of pebble fabric data exhibiting multimodal distributions (Cornish, 1979). The magnitude of the resultant vector ( $L \%$ ) which is calculated in two-dimensional vector analysis (Krumbein, 1939; Curray, 1956) was used as a measure of fabric strength.

The effects of three variables on fabric data were analysed (Table IV; Fig.11):

1. Operator vamiation. As the fabrics were measured by three persons it was necessary to consider the influence of operator variation. Operator 1 measured 14 fabrics, which had a mean vector magnitude of $41.74 \pm 20.62 \%$, while Operator 2 measured 21 fabrics with a mean vector magnitude of $41.70 \pm 12.99 \%$. The third operator only measured two fabrics. In view of the similarity of the results obtained by Operators 1 and 2 , operator variance was not considered to affect the results significantly.

2. Depth of sample below midge crest. Two zones can be distinguished: an upper zone 1.2 to $1.5 \mathrm{~m}$ thick, in which vector magnitudes are generally less than $40 \%$ and in which a variety of fabric types occur, and a lower zone in which vector magnitudes are greater (mean of $4=65.3 \pm 8.64 \%$ ). Of 33 fabrics in the upper zone, 11 showed no significant preferred orientation, while all those in the lower zone showed a significant preferred orientation and dip (Fig.11 a,b). The lower-zone fabrics are typical of undisturbed lodgement tills (Mickelson, 1973; Krüger, 1979; Krüger and Thomsen, 1981), while those in the upper zone appear to reflect disturbance and reorientation during ridge formation. The thickness of the upper zone is approximately equivalent to the height of the ridges above the adjacent till surface.

3. Position of sample in relation to the midge crestline. For purposes of comparison, each fabric was allocated to one of three zones, proximal, central, and distal. The central zone was defined as a column $1 \mathrm{~m}$ wide, $0.5 \mathrm{~m}$ on either side of the ridge crest. The vector magnitudes of the fabrics do not seem to 


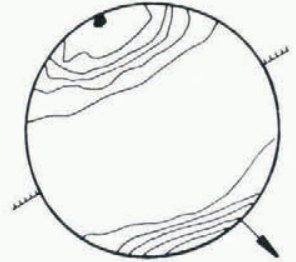

$A: N$ is $25: L$ is $72.8 \%$ : Type A

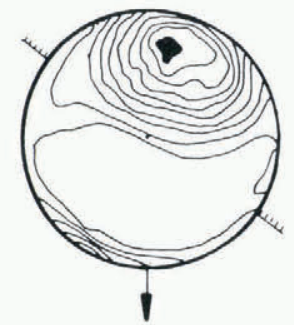

$E: N$ is $50: L$ is $54.2 \%$ :

Type A

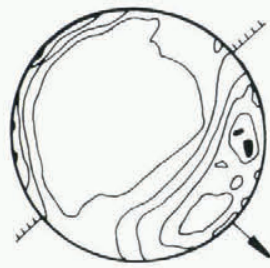

I: $N$ is $50: L$ is $24.2 \%$ : Type C

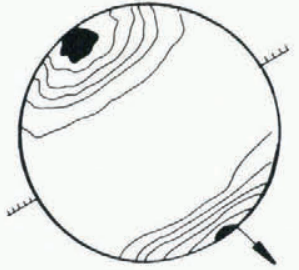

$B: N$ is $25: L$ is $72.6 \%$ : Type A

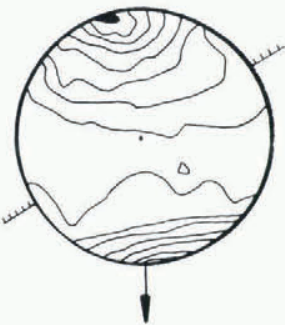

$\mathrm{F}: \mathrm{N}$ is $50: \mathrm{L}$ is $57.4 \%$ : Type A

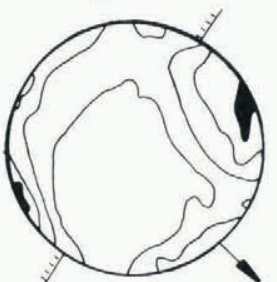

$\mathrm{J}$ : $N$ is $50: L$ is $29.9 \%$ : Type C

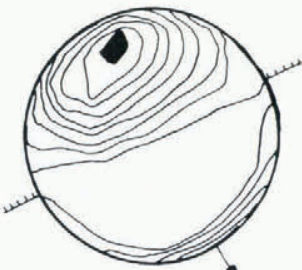

C: $N$ is $50: L$ is $41.4 \%$ Type A

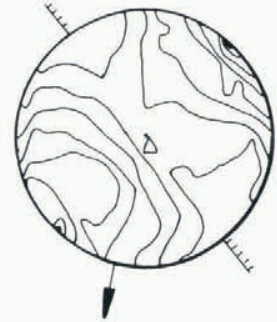

G: $N$ is $50: L$ is $53.4 \%$ : Type B

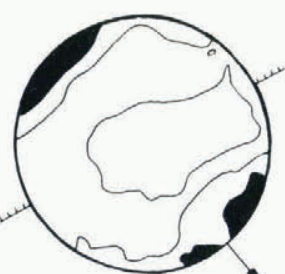

$D: N$ is $25: L$ is $23.0 \%$ : Type D

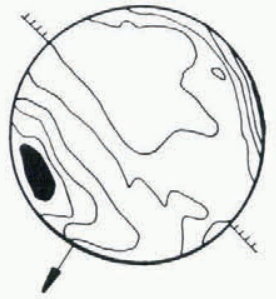

$\mathrm{H}: \mathrm{N}$ is $50: \mathrm{L}$ is $37.0 \%$ : Type A a. Undisturbed lodgement till beneath proximal slope of midge.

$b$. Undisturbed lodgement till beneath distal slope of idge.

c-e. Proximal position.

f. Centre of ridge.

g-i. Distal position.

j. Surface fabmic, distal side of midge crest.

Fig.11. Schmidt equal-area nets showing the long-axis omentation of clasts from "annual" moraine midges at skalafellsjökull. Diagrams are contoured at 20 according to the method of Kamb (1959). N, number of stones; $L$, vector magnitude; $A, B, C, D$, type of fabric as defined by the $A_{n}$ statistic of Ajne (1968) and Stephens (1969); arrow indicates local ice-flow direction; pecked line indicates orientation of midge crest-line.

vary with position, but fabric types do. Whilst $54.5 \%$ of fabrics in proximal and central positions have significant preferred orientations and dips, only $26.7 \%$ of those in distal positions do so. All the proximal fabrics with a significant dip (Types $A$ and $C$ ) dip upglacier (Fig.11 d-g), but $37.5 \%$ of those in distal positions dip down-glacier (Fig.11 h-j). When Type B fabrics are included in the analysis, $66.7 \%$ distal fabrics exhibit a down-glacier dipping element, while only $16.6 \%$ proximal fabrics do so. This difference is significant at the 0.05 level ( $x^{2}$ test; $\left.x^{2}=8.61\right)$.

In all but two of the fabrics with a significant preferred orientation, that orientation was approximately parallel to the local ice-flow direction

(Fig.11 a-i). In two cases, however, it was almost parallel to the ridge crest-line (Fig.l1 j). Both of these fabrics were measured on the surface of a ridge on the distal side of its crest. Lawson (1979[a], 1981) concluded that fabrics of this type are formed at locations where material released from glacier ice accumulates at the foot of a steep ice slope, and he referred to the resultant deposit as ice-slope colluvium. As the location of the two fabrics is consistent with such an origin and this depositional process has been observed on some actively forming ridges, it is suggested that these two fabrics reflect a surface veneer of ice-slope colluvium.
Four Type D fabrics (no significant preferred orientation or dip) were measured in surface positions on the proximal slopes of ridges (the depth measurements given in Table IV are relative to the ridge crest rather than the ground surface). Such fabrics are typical of sediment flow deposits (Lawson, 1979[a], [b], 1981), and as sediment flows do occur on the proximal slopes of some recently formed ridges, these four fabrics are attributed to sediment flow deposition.

An idealized model of the internal fabric of the ridges is presented in Figure 12. Neglecting the surface veneer of resedimented debris, the fabric of the ridge core takes the form of an asymmetrical fold that mimics ridge morphology and is identical to the structure depicted by the sand and silt laminae in some ridges. The deformed ridge core overlies a zone of undisturbed lodgement till at depth. These observations suggest that ridge formation involved the deformation of the surface layers of previously deposited sediment. The fabrics dipping up-glacier found in the proximal parts of the ridges are similar to the fabrics of the Fjallsjökull ridges which Price (1970) believed were formed by squeezing of water-soaked till from beneath the glacier margin. The fabrics dipping down-glacier in the distal parts of the ridges are similar to the fabrics of "push ridges" at Blaisen, Norway described by Derbyshire and others (1976). 


\section{CHRONOLOGY OF RIUGE FORMATION}

In order to test the hypothesis that the ridges form annually in association with winter re-advances of the glacier margin, an attempt was made to determine whether the number and spacing of ridges was related to the annual measurements of glacier retreat made by the Iceland Glaciological Society. These measurements began in the summer of 1930 when

H.H. Eiriksson established a series of cairns in the pro-glacial area of Skálafellsjökulı (Eiriksson, 1932). The position of the ice front relative to Eiriksson's Cairn 46 was recorded each year from 1930 to 1972 along a line of transect which is clearly demarcated on the ground by stakes and painted boulders (Fig.1) (Eythórsson, 1963; Rist [1976]).

This transect was surveyed in summer 1980 by Abney-level and tape traverse, during which the crestline positions of all ridges were noted. These ridges could then be dated by comparing their location with ice margin positions reconstructed from the glacier retreat measurements, and their number and spacing could be compared with the annual retreat rates. A subjective estimate of the error inherent in this dating method is one or two years, arising from surveying errors and possible effects of overriding and superposition of ridges. This was thought to be a particular problem for the period 1930-35 since the glacier made a net advance of $5 \mathrm{~m}$ between 1932 and 1933, and it was not clear whether this advance destroyed any previously deposited ridges. As a result, detailed comparisons of ridge spacing and retreat rates were restricted to the period 1937-61, when the glacier was in continuous retreat. Up-glacier from the 1961 ridge, the transect line crosses a proglacial lake and no more ridges are visible.

25 ridges were constructed in the area deglaciated between 1937 and 1961, and the correspondence between ridge spacing and measured retreat rates is generally very good (Fig.13; $r=0.53, p<0.005)$. The most notable residual occurs in 1939, when the ridge spacing is almost double the measured retreat rate. It is, however, equivalent to the sum of the 19381939 and 1939-40 retreat rates, perhaps indicating that no ridge formed along this part of the ice front in 1939, and that the measured spacing is in fact the distance between ridges formed in 1938 and 1940. Retreat rates in the late $1930^{\prime}$ 's were the most rapid

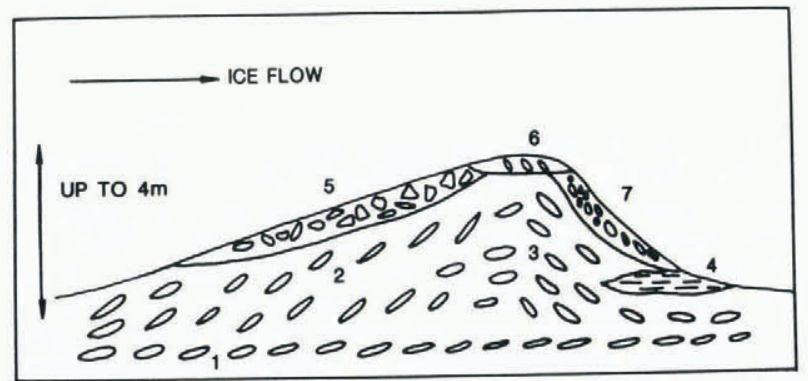

Fig.12. Idealized model of the intemal fabric of an "annual" moraine midge at skalafellsjökull. Not all elements are necessamily present in all midges. 1. Undisturbed lodgement till. Strong preferred orientation, and low up-glacier dip.

2. Disturbed lodgement till. Weaker fabmic with steeper up-glacier dip.

3. Disturbed lodgement till with down-glacier dipping fabric element.

4. Laminated sands and silts overriden during the advance which formed the midge.

5. Sediment flow deposits. No preferred orientation, slope-conformable dip.

6 . Ice slope colluvium. Weak preferred omientation parallel to the midge crest.

7. Avalanched debmis showing down-slope sizesorting. this century $\left(1933-40\right.$ mean $\left.=32 \mathrm{~m} \mathrm{a}^{-1}\right)$ and ridges may not have formed when retreat was most rapid. Support for this idea comes from nearby Breiðamerkurjökull, where ridges have only formed since 1965. During the period 1965-1980 the retreat rate of the glacier at west Breida dropped from its 1933-65 average of $42.9 \mathrm{~m} \mathrm{a}^{-1}$ to an average of $29.3 \mathrm{~m} \mathrm{a}^{-1}$ (Jarvis, 1980). Retreat rates at Skálafellsjökull have always been less than at Breiðamerkurjökull, averaging only $26.8 \mathrm{~m} \mathrm{a}^{-1}$ over the period 1931-60, and ridges have formed over a much longer period. The spacing of ridges at Skálafellsjökull was significantly correlated with the mean summer (May to September) temperature measured at Fagurhólmsmýri (Fig.1) over the period 1937-61 $(r=0.445 ; p<0.05)$. This result, and the generally good correspondence between the number and spacing of ridges and the measured glacier retreat rates, suggests that the ridges were formed annually. A better correlation is probably precluded by a number of unknowns which affect the results. These include:

1. The possibility that retreat measurements were not made on the same day each year;

2. The fact that the measurements give only a smoothed picture of actual glacier fluctuations;

3. The possibility that the timing of ridge construction may have varied from year to year;

4. The possibility that ridges may not have formed in each year along the particular transect studied.

If the ridges were indeed formed annually, it is likely that they have formed since about 1912 because there are a further 18 ridges between the 1887 end moraine and Eir'́ksson's Cairn 46 which was established in 1930.

\section{EVOLUTION OF RIDGE MORPHOLOGY}

On the assumption that the ridges were formed annually, recent ridges formed along those parts of the glacier margin not fronted by pro-glacial lakes can be approximately dated by counting the number of ridges between them and the present ice front. By placing these ridges and those formed between 1937 and 1961 in an approximate age sequence, it is possible to consider the evolution of ridge morphology over time.

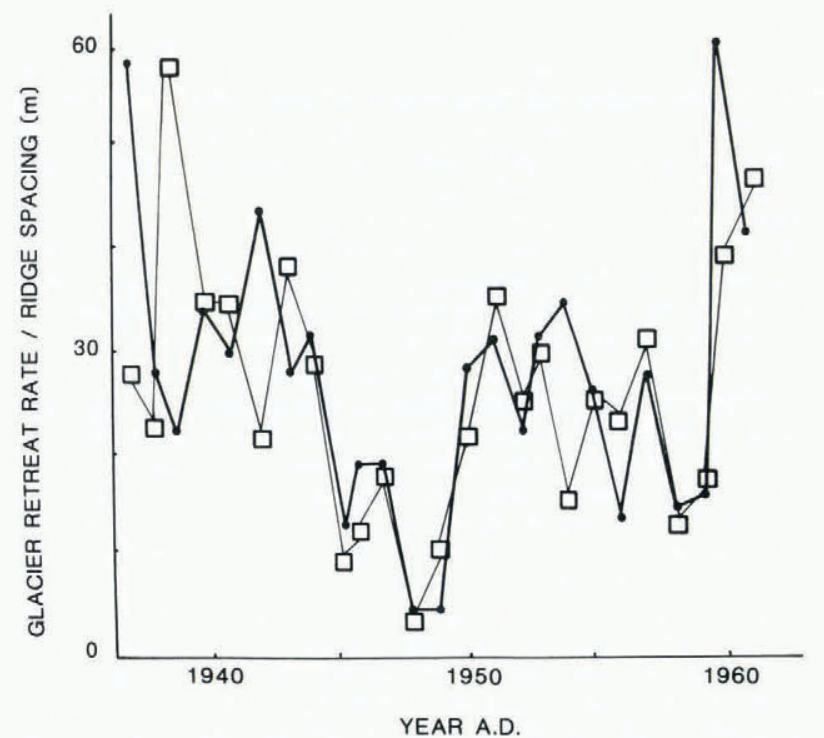

Fig.13. Variations in the spacing of "annual" moraine midges () at skalafellsjokuli, and in the retreat rate of the glacier (-) during the period 1937-61. 
The mean of the maximum slope angles recorded on the profiles across each of the ridges in Table I was calculated and plotted as a function of ridge age (Fig.14). Immediately after ridge formation there is a rapid decline in maximum slope angle from $34.2 \pm 1.89^{\circ}$ on a one-year-old ridge, to $27 \pm 3.44^{\circ}$ on a five-year-old ridge and $21.95 \pm 3.2^{\circ}$ on a ten-year-old ridge. After ten years there seems to be relatively little change, with maximum slope angles on ridges between 17 and 43 years old averaging between $18.1 \pm 2.7^{\circ}$ and $19.7 \pm 1.15^{\circ}$. The anomal ously steep-sided 51 year-old ridge is composed almost entirely of boulders, and is unlikely to be affected by sediment gravity flow (Sharp, unpublished; Lawson, 1982), the process which is observed to be responsible for much of the initial degradation of ridges.

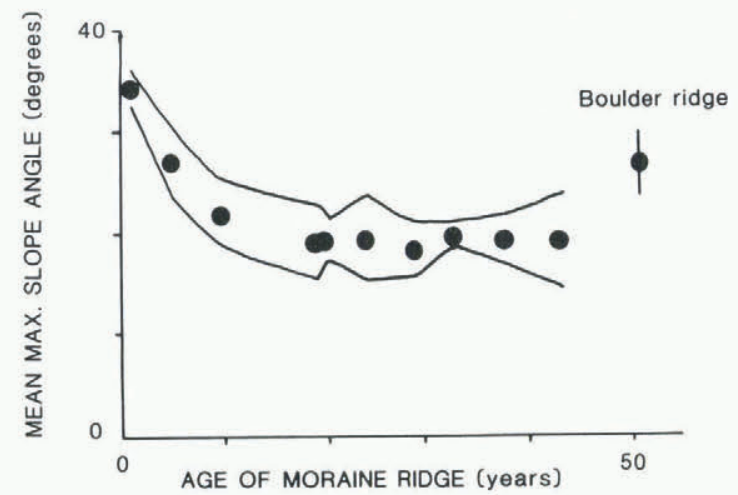

Fig.14. Mean maximum slope angle $( \pm 1$ standard deviation) of "annual" moraine midges at Skálafellsjökull plotted as a function of midge age.

The mean maximum slope angle of the one-year-old ridge lies within the range of angles of internal shearing resistance $\left(\phi^{\prime}\right)$ measured by Boulton and Dent (1974) on Breiðamerkurjökull lodgement tills $\left(24-39^{\circ}\right)$. If $\phi^{\prime}$ is assumed to have a value of $34.2^{\circ}$ for Skálafells sökull tills, the evolution of the ridge slopes can be successfully predicted using a simple stability model, in which a threshold slope angle $B C$ is given by:

$$
\tan \beta_{C}=\frac{\rho_{\mathrm{S}}-m \rho_{\mathrm{W}}}{\rho_{\mathrm{S}}} \tan \phi^{\prime} \approx \frac{1}{2} \tan \phi^{\prime}
$$

where $\rho_{S}$ and $\rho_{W}$ are saturated bulk density and water density, and $m$ is the relative height of the water table above the shear plane (Anderson and others, 1980). Assuming regolith saturation, with the water table at the surface and drainage along flow lines parallel to the surface, $m$ is equal to unity. For $\phi^{\prime}=34.2^{\circ}, \beta c=18.75^{\circ}$, a value very close to the mean maximum slope angles of ridges over ten years old.

The existence of visible evidence for the evolution of ridge slopes by mass movement suggests that it is realistic to adopt a stability analysis to interpret the angle of straight slope segments. Despite the agreement between predicted values of $B C$ and measured slope angles, more information on shear-plane morphology, the lateral extent of slides, and pressure patterns of the pore water would be required to determine whether the simple model adopted is a realistic representation of the conditions responsible for failure (Anderson and others, 1980). Nevertheless, the results suggest that, on most slopes, conditions sufficient to cause failure are experienced within ten years of ridge construction.

\section{DISCUSSION: PROCESSES OF RIDGE FORMATION}

Minor moraines seem to have formed annually at Skálafellsjökull since about 1912. Most ridges were formed at the ice margin, form concentric arcs about the glacier, and have a plan form which reflects details of the ice-front morphology. Some ridges consist almost entirely of boulders, but most have a core composed of material derived from the dilatant upper horizon of lodgement tills which have undergone subglacial shearing. Such ridges overlie undisturbed, compacted lodgement tills at depth. Ridges are asymmetrical, with steeper distal slopes, and their morphology appears to reflect their internal structure. This is an asymmetric fold with steeper distal limb and axial plane dipping up-glacier. Some ridges have a surface veneer of resedimented debris consisting of ice-slope colluvium and sediment flow deposits. Such a veneer usually indicates the presence or former presence of an ice core in the ridge. Certain characteristics of the ridges such as the concentration of large boulders into lines parallel to the ice front, and the incorporation of proglacially-deposited sediments suggest that the formation of at least some ridges involves a re-advance of the glacier. On an annual time-scale such re-advances are most likely to occur in late winter or early spring. Whilst it is not certain that ridges cannot form in the absence of a glacier re-advance, their apparent failure to form in years of particularly rapid ice retreat suggests that this may be the case. Whilst the contribution to ridge formation of such processes as sediment flow and the bulldozing of large boulders by the glacier is relatively clear, it is more difficult to identify the processes involved in the formation of the core of ridges composed of deformed lodgement till. Of six possible ridge-forming processes discussed by Worsley (1974), only two involved the deformation of previously deposited sediments. These were glacial push during a re-advance, and the squeezing of water-saturated till to the margin under static loading of the ice. However, although both these processes may be involved in the formation of the Skalafells jökull ridges, neither provides a wholly satisfactory explanation.

Instead, an alternative model is proposed which couples the ridge-forming process to the subglacial deformation of lodgement tills. Boulton and Jones (1979) recorded maximum velocities of $40 \mathrm{~cm}$ in $10 \mathrm{~d}$ in deforming subglacial tills at Breiðamerkurjökull, and such velocities must result in a net discharge of sediment towards the glacier margin. According to Boulton $(1979, p .31)$, "If the glacier front were to remain stationary, the effect of this process would be to create a submarginal depression parallel to the ice-front. If retreat of the glacier were irregular, depressions would develop where glacier retreat was relatively slow." A corollary of this is that till removed from depressions must accumulate at the near stationary ice front, and it may also be extruded from beneath the ice in response to the pressure gradient which exists at the margin. This process would tend to produce pebble fabrics dipping up-glacier such as are observed in the proximal parts of the ridges (Derbyshire, 1979). On an annual time scale this is most likely to occur in winter when ablation rates are lowest, and if, as seems likely, a glacier re-advance should occur at this time, it would probably bulldoze the extruded sediments, producing pebble fabrics dipping down-glacier in the distal parts of the ridge where the sediments would be overturned (Derbyshire, 1979; Derbyshire and others, 1976).

This mode of formation requires that the glacier remain active during retreat, and is consistent with the observation that annual moraines are absent from the pro-glacial areas of surging outlet glaciers of Vatnajökull (Sharp, unpublished). The terminal areas 
of these glaciers become stagnant during the quiescent period between surges, and they are incapable of bulldozing any sediments extruded from beneath the glacier margin. This observation suggests that the occurrence of annual moraines may provide strong evidence that a glacier is not a surging glacier.

\section{ACKNOWLEDGEMENTS}

This work was carried out during tenure of a United Kingdom Natural Environment Research Council (NERC) studentship in the Department of Geography, University of Aberdeen. Permission to work at Skálafellsjökull was kindly given by the Icelandic National Research Council. Patricia Sharp, Julian Dowdeswel1, Campbel1 Gemmel1, and Jennifer MacNeill provided invaluable field assistance, and grants from the Royal Geographical Society contributed towards their expenses. Susan Kennedy undertook particle-size analysis; Dr M.J. Wilson provided information on clay mineralogy; Dr Daniel Lawson, Dr Alistair Gemmel1, and Rodger Connell provided computer programs used in the analysis, and Drs Daniel Lawson, Harold Reading, and David Sugden made constructive criticisms of an earlier draft.

\section{REFERENCES}

Ajne, B. 1968. A simple test for uniformity of a circular distribution. Biometrika, Vol. 55, No. 2, p. 343-54.

Andersen, J.L., and Sollid, J.L. 1971. Glacial chronology and glacial geomorphology in the marginal zones of the glaciers Midtdalsbreen and Nigardsbreen, south Norway. Norsk Geografisk Tidsskrift, Bd 25, Ht. 1, p. 1-38.

Anderson, M.G., and others. 1980. The role of stability analysis in the interpretation of the evolution of threshold slopes, by M.G. Anderson, K.S. Richards, and P.E. Kneale. Institute of British Geographers. Transactions, Vol. 5, No. 1, p. 100-12.

Birnie, R.V. 1977. A snow-bank push mechanism for the formation of some "annual" moraine ridges. Joumal of Glaciology, Vol. 18, No. 78, p. 77-85.

Birnie, R.V. Unpublished. Rock debris transport and deposition by valley glaciers in South Georgia. [Ph.D. thesis, University of Aberdeen, 1978.]

Boulton, G.S. 1978. Boulder shapes and grain size distribution of debris as indicators of transport paths through a glacier and till genesis. Sedimentology, Vol. 25, No. 6, p. 773-99.

Boulton, G.S. 1979. Processes of glacier erosion on different substrata. Joumal of Glaciology, Vol. 23, No. 89 , p. $15-38$.

Boulton, G.S., and Dent, D.L. 1974. The nature and rates of post-depositional changes in recently deposited till from south-east Iceland. Geografiska Annaler, Vol. 56A, Nos. 3-4, p. 121-34.

Boulton, G.S., and Jones, A.S. 1979. Stability of temperate ice caps and ice sheets resting on beds of deformable sediment. Joumal of Glaciology, Vol. 24 , No. 90, p. 29-43.

Boulton, G.S., and others. 1974. Subglacial shearing and crushing, and the role of water pressures in tills from south-east Iceland, by G.S. Boulton, D.L. Dent, and E.M. Morris. Geografiska Annater, Vol. 56A, Nos. 3-4, p. 135-45.

Bowden, F.P. and Tabor, D. 1950. The friction and Zubrication of solids. Part 1. Oxford, Clarendon Press. (International Series of Monographs on Physics.)

Cornish, R. 1979. The statistical analysis of till fabric data: a review. University of Edinburgh. Dept. of Geography. Research Discussion Paper No.16.

Curray, J.R. 1956. The analys is of two-dimensional orientation data. Joumal of Geology, Vol. 64, No. 2 , p. 117-31.
Dale, M.L., and Ballantyne C.K. 1980. Two statistics for the analysis of orientation data in geography. Professional Geographer, Vol. 32, No. 2, p. 184-91.

Derbyshire, E. 1979. Cryonival and glacial processes. (In Derbyshire, E., and others. Geomorphological processes, [by] E. Derbyshire, K.J. Gregory, J.R. Hails. Folkestone, Wm. Dawson and Sons, Ltd.; Boulder, Colorado, Westview Press, Inc., p. 187-285.)

Derbyshire, E., and others. 1976. "Total" fabric of some till landforms, [by] E. Derbyshire, A. McGown, and A. Radwan. Earth Surface Processes. Vol. 1, No. 1 , p. 17-26.

Eiriksson, H.H. 1932. Observations and measurements of some glaciers in Austur-Skaftafellssȳsla in the summer 1930. Vîsindafélag Islendinga, 12, p. 3-24.

Eyles, N. 1979. Facies of supraglacial sedimentation on Icelandic and Alpine temperate glaciers. Canadian Joumal of Earth Sciences, Vol. 16, No. 7, p. 1341-61. Eythörsson, J. 1963. Variation of Icelandic glaciers 1931-1960. jökulz, Âr 13, p. 31-33.

Folk, R.L., and Ward, W.C. 1957. Brazos river bar: a study in the significance of grain size parameters. Joumal of Sedimentary Petrology, Vol. 27, No. 1, p. $3-26$.

Jarvis, J. 1980. The development of moraines at Breidamerkurjökull and Fjallsjökull, south-east Iceland. (In [Jarvis, J., ed.] Breidamerkurjökull expedition report. [St. Andrews], Dept. of Geography, University of St. Andrews, p. 29-45.)

Kamb, W.B. 1959. Ice petrofabric observations from Blue Glacier, Washington, in relation to theory and experiment. Joumal of Geophysical Research, Vol. 64, No. 11 , p. 1891-909.

Kasser, P. 1967. Fluctuations of glaciers, 1959-1965. A contribution to the Intemational Hydrological Decade. [Gentbrugge], International Commission of Snow and Ice of the International Association of Scientific Hydrology.

Krüger, J. 1979. Structures and textures in till indicating subglacial deposition. Boreas, Vol. 8 , No. 3 , p. 323-40.

Krüger, J., and Thomsen, H.H. 1981. Till fabric i et recent bundmoraenelandskab, Island. Dansk Geologisk Forening.Arsskmift for 1980, p. 19-28.

Krumbein, W.C. 1939. Preferred orientation of pebbles in sedimentary deposits. Joumal of Geology, Vol. 47, No. 7 , p. 673-706.

Lawson, D.E. 1979[a]. A comparison of the pebble orientations in ice and deposits of the Matanuska Glacier, Alaska. Joumal of Geology, Vol. 87, No. 6, p. 629-45.

Lawson, D.E. 1979[b]. Sedimentological analysis of the western terminus region of the Matanuska Glacier, Alaska. CRREL Report (Hanover, N.H.) 79-9.

Lawson, D.E. 1981. Distinguishing characteristics of diamictons at the margin of the Matanuska Glacier, Alaska. Annals of Glaciology, Vol. 2, p. 78-84.

Lawson, D.E. 1982. Mobilization, movement, and deposition of active subaerial sediment flows, Matanuska Glacier, Alaska. Jourmal of Geology, Vol. 90, №. 3, p. 279-300.

Matthews, J.A., and others. 1979. "Saw-tooth" moraines in front of $B \phi d a l s b r e e n$, southern Norway, by J.A. Matthews, R. Cornish, and R.A. Shakesby. Jour nal of Glaciology, Vol. 22, No. 88, p. 535-46.

Mickelson, D.M. 1973. Nature and rate of basal till deposition in a stagnating ice mass, Burroughs Glacier, Alaska. Arctic and Alpine Research, Vol. 5, No. 1, p. 17-27.

Powers, M.C. 1953. A new roundness scale for sedimentary particles. Journal of Sedimentary Petrology, Vol. 23, No. 2, p. 117-19.

Price, R.J. 1970. Moraines at Fjallsjökul1, Iceland. Arctic and Alpine Research, Vol. 2, No. 1, p. 27-42.

Rains, R.B., and Shaw, J. 1981. Some mechanisms of controlled moraine development, Antarctica. Joumal of Glaciology, Vol. 27, No. 95, p. 113-28.

Rist, S. [1976.] Jöklabreytingar 1931/64, 1964/74, og 1974/75. jökull, Ar 25, 1975, p. 73-79. 
Rogerson, R.J., and Batterson, M.J. 1982. Contemporary push moraine formation in the Yoho Valley, B.C.

(In Davidson-Arnott, R., and others, ed. Research in glacial, glacio-fluvial, and glaciolacustrine systems). Proceedings of the 6th Guelph Symposium on Geomorphology, 1980. Edited by R. Davidson-Amott, W. Nickling, B.D. Fahey. Norwich, Geo Books in association with Geomorphology Symposium, University of Guelph, p. 71-90.)

Romans, J.C.C., and others. 1980. The micromorphology of young soils from south-east Iceland, by J.C.C. Romans, L. Robertson, and D.L. Dent. Geografiska Annaler, Vol. 62A, Nos. 1-2, p. 93-103. Saemundsson, K. [1980.] Outline of the geology of Iceland. Jökull, Ar 29, 1979, p. 7-28.

Sharp, M.J. 1982. Modification of clasts in lodgement tills by glacial erosion. Joumal of Glaciology, Vol. 28, No. 100 , p. 475-81.

Sharp, M.J. Unpublished. A comparison of the landforms and sedimentary sequences produced by surging and non-surging glaciers in Iceland. [Ph.D. thesis, University of Aberdeen, 1982.]

Siegel, S. 1956. Nonparametric statistics for the behavioral sciences. New York, McGraw-Hill Book Co. (in collaboration with Kogakusha Co., Ltd., Tokyo).
Slatt, R.M., and Eyles, N. 1981. Petrology of glacial sand: implications for the origin and mechanical durability of lithic fragments. Sedimentology, Vol. 28 , No. 2, p. 171-83.

Stephens, M.A. 1969. A goodness-of-fit statistic for the circle, with some comparisons. Biometrika, Vol. 56 , No. 1, p. 161-68.

Thorarinsson, S. 1943. 0scillations of the Iceland glaciers in the last 250 years. Geografiska Annaler, Arg. 25, Ht. 1-2, p. 1-54.

Thorarinsson, S. 1967. Forvitnilegir jökulgarðar við jaðar Skeið̋arärjökuls [Washboard moraines in front of Skeiðarárjökull]. Jökull, Ar 17, p. 311-12. [English abstract.]

Walker, G.P.L. 1964. Geological investigations in eastern Iceland. Bulletin Volcanologique, Tom. 27, No. 1 , p. 351-63.

Worsley, P. 1974. Recent "annual" moraine ridges at Austre Okstindbreen, Okstindan, north Norway. Jour nal of Glaciology, Vol. 13, No. 68, p. 265-77.

Zingg, T. 1935. Beitrag zur Schotteranalyse. Schweizerische Mineralogische und Petrographische Mitteilungen, Bd. 15, Ht. 1, p. 38-140. 